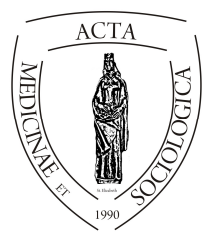

doi:

\title{
Social Exclusion of Pervitin Users
}

\author{
Nikola Brandová ${ }^{1}$, Alena Kajanová ${ }^{2}$ \\ ${ }^{1}$ University of South Bohemia in České Budějovice: České Budějovice, CZ \\ ${ }^{2}$ University of South Bohemia in České Budějovice: České Budějovice, CZ
}

\begin{tabular}{|c|c|}
\hline INFO & ABSTRACT \\
\hline $\begin{array}{l}\text { Nikola Brandová } \\
\text { nikusab@seznam.cz }\end{array}$ & \multirow[b]{2}{*}{$\begin{array}{l}\text { Abstract. The article is based on a qualitative study using } \\
\text { narrative interviews with } 13 \text { South Bohemian Pervitin users } \\
\text { who visit the drug advisory centre. The goal of the article is } \\
\text { to describe how social exclusion is subjectively experienced } \\
\text { by Pervitin users. The data were processed with the help of } \\
\text { grounded theory. The respondents feel to be excluded in a } \\
\text { number of normal life areas: they are rejected by their } \\
\text { family, friends, and also by public institutions - particularly } \\
\text { by the police and by health care facilities. } \\
\text { Social exclusion is accompanied by feelings of guilt and } \\
\text { remorse for the users. They are also ashamed of their } \\
\text { situation, feeling sorrow and disappointed themselves. In } \\
\text { some cases, the users are angry with themselves, in other } \\
\text { cases with their surroundings for rejecting them. In both } \\
\text { variants, exclusion may constitute an important factor in } \\
\text { reducing the users' chances of abstinence. }\end{array}$} \\
\hline $\begin{array}{l}\text { Keywords } \\
\text { social exclusion; pervitin } \\
\text { users; drugs; public } \\
\text { institution }\end{array}$ & \\
\hline $\begin{array}{l}\text { Kulcsszavak: } \\
\text { kirekesztés, pervitin- } \\
\text { fogyasztók, drog, köz- } \\
\text { szolgáltatások }\end{array}$ & $\begin{array}{l}\text { Absztrakt. A cikk egy kvalitatív kutatásra épül, ami narratív } \\
\text { kérdőív segítségével } 13 \text { dél-csehországi Pervitin használóval } \\
\text { készült, akik rendszeresen ellátogattak a drogprevenciós és } \\
\text { tanácsadó központba. A cikk célja megmutatni, hogy a } \\
\text { Pervitin használók hogyan élik meg a társadalmi kirekesztö- } \\
\text { dést. A válaszadók úgy érzik, hogy a normális élet számos } \\
\text { területéről kiszorulnak: elutasítja őket a család, a barátaik és } \\
\text { a közintézmények, különösképpen a rendőrség és az egész- } \\
\text { ségügyi intézmények. } \\
\text { A társadalmi kirekesztődéssel együtt jár a büntudat és a } \\
\text { felhasználók iránt érzett sajnálat.. Szégyellik a helyzetüket, } \\
\text { szomorúak és csalódottak magukban. Van, hogy magukra } \\
\text { haragszanak, van, hogy a környezetükre, amiért elutasítják } \\
\text { őket. Mindkét esetben fontos tényező lehet a kirekesztődés } \\
\text { ami csökkenti a szerhasználó absztinensé válásának esélyeit. }\end{array}$ \\
\hline
\end{tabular}




\section{Introduction}

According to Popay et al. (2008), social exclusion is defined as a process or condition restricting specific individuals, families, groups or even whole communities in having access to the resources needed for participation in social, economic and political life of the society. In its consequence, exclusion constitutes unequal chances for the persons concerned. The origination and development of social exclusion is multidimensional, with effects of internal (low education, personality characteristics, handicaps, etc.) and external (structural inequality in the labour market, stigmatization, etc.) factors whose interconnection leads to continuous deepening of the condition and to reduction of the chances of the excluded persons to break out.

The impacts of social exclusion are described by Ziyauddin (2009) in the following dimensions. The first dimension in the list is the economic dimension, manifested in restricted access to the labour market. The second dimension is the cultural dimension related to a low education level, also related to restricted opportunities to participate in the culture of non-excluded individuals. The third, social dimension, consists of restriction of social relations exclusively to persons living in the same subculture. The last dimension, discussed by Bernhard (2006), is the symbolic dimension, sometimes called subjective exclusion and characterized by stigmatizing designation and perception of the excluded persons. This dimension can be often found in groups whose dissimilarity is perceived by the majority society as deviant or "immoral". That leads to the marginalization of the members of such groups.

The literature presents two views of the connection of use a habit-forming substance and of the phenomenon of social exclusion. The first view deals with social exclusion as a consequence of problematic use of drugs. The use of a habit-forming substance is the "driving force" of the transition from normal life to exclusion when the addicted persons grow away from their families, friends, previous style of life, the labour market, and get involved with the chaotic, destructive trap of addiction. Drug addiction enters different areas of the individual's life and the problems emerging in the social area, the stigma, discrimination and prejudices related to drug use may lead the user to the margin of the society and to social exclusion (MacDonald, 2006). The social exclusion may have the form of self-exclusion - when the addicted persons are so concentrated on their addiction that they adapt voluntarily their whole life to drugs. Problematic drug users may also be excluded by their closest surroundings (particularly by their families) when they lose their job or give up most of their roles (Ryczkowska 2009).

The second view is focused on the opposite sequence of the given phenomena. It considers social exclusion as the cause of the problematic use of habit-forming substances. Problematic drug users often come from poor and socially excluded communities. They have restricted opportunities for choice and experience disadvantage. Socially excluded individuals are driven to the use of hard drugs by feelings of separation, alienation and hopelessness (Neale 2006). Additionally to 
fun, the habit-forming substances may offer an economic opportunity, increased prestige, they may dampen the feelings of dissatisfaction and helplessness and help the individual to create a new identity. The drug career may be perceived as a challenge and, in itself, it may constitute an opportunity of self-fulfilment, particularly in case that other opportunities are restricted or inaccessible due to social exclusion (Adams 2008).

Social exclusion that may be characterized by decomposition of the family, bad housing, bad health condition, limited education, unemployment, crime, etc. increases the probability for the individuals to use drugs in a problematic manner. In the meantime, the problem of drug use may lead to further social exclusion (in form of more family problems, increased housing problems, worsened health condition, increased probability of unemployment, increased crime, etc.) (Buchanan 2005).

\section{Materials and methods}

The goal of the article consists of describing how social exclusion is subjectively experienced by pervitin users. The goal leads to the research question: In which areas of pervitin users' life does the social exclusion become evident? The study used a qualitative research design. The data were collected through narrative interviews. A narrative interview is a specific form of an open, unstructured interview. Such interview assumes that there are subjective significance structures that will come out during the free narration, not during targeted questioning (Flick 2009). The communication partners were asked the following basic question: Can you tell me the story of your drug career?

In the interviews with the communication partners, we focused on the period of their drug career, and in the interviews with abstaining persons, we also talked about the time when the use of pervitin was not a part of their lives. The interviews took from 30 to 55 minutes, were verbatim transcribed and subsequently analyzed. When analyzing the transcribed data, we focused on the topic of social exclusion. The data were processed by open coding and the results are completed with quotations typical for the individual categories.

The study was implemented on the territory of the Czech Republic, namely within the South Bohemian Region. The research set consisted of pervitin users visiting the Prevent Contact Centre in České Budějovice, Prachatice and Strakonice and the Addictology Advisory Centre in České Budějovice. Those facilities are devoted to working with the users of habit-forming substances. The study included 13 communication partners, 6 of them abstaining and 7 of them currently using drugs. The sample consisted of 8 women and 5 men; the youngest communication partner was 18 years old, the oldest was 35 years old; the period of use of pervitin oscillated from 1,5 year to 17 years. 


\section{Results}

\subsection{Drugs as a cause of exclusion}

In the interviews, the pervitin users described different forms of their exclusion from the majority society due to their drug career. The closest circle of persons rejecting the communication partners includes their family members. After finding out that their relative uses habit-forming substances, the family members often turn away and their mutual relations get considerably worsened or interrupted: "At home, when it came out, there was much rage. My mum finds needles in my things and she immediately called me to tell me that she found the needles and she started checking me and she saw that I had needle marks. She was very angry and did not talk to me much, and the same was my whole family. "(M., 19 years).

Another area where the pervitin users reported a negative attitude includes contacts with representatives of different institutions. They mentioned for example unpleasant experience with the police or with health care staff: „, Yes, that happens, for example when you have wounds and need treatment, so it happens that the doctor throws you out and so on. " (T., 31 years). But the users face condemnation and rejection not only within institutions but in the society in general. Their friends turn their back to them and people who are in contact with them condemn them for using the drug and approach them more negatively than persons not using any drugs: „,Well, it is quite simple, they look differently at you and turn against you straight away. "(E., 28 years).

Further, the communication partners described the feelings experienced by them in connection with the use of the drug and with the reactions of the surrounding persons. They often report feelings of guilt and remorse. They are also ashamed of their situation, feeling sorrow about and disappointment of themselves. Sometimes, the users are angry with themselves, in other cases with their surroundings for rejecting them. They feel uneasy because of other people avoiding their company: "You simply feel, how to say it, not quite like scraping the living, but like having plague or something like that. They need not say it, they only pass by you and you see that they say to themselves, yeah, you are a druggie. It is quite terrible, yes. "(T., 31 years).

\subsection{Dimensions of social exclusion in relation to drug abuse}

In connection with the economic dimension of social exclusion, it was mentioned that the pervitin users are not able to keep their job, losing the chance of a regular income and becoming unemployed due to the drug: "I had a job but I never managed to work for a long time." (V., 30 years). Therefore, in many cases, the users get the means of subsistence and the money for the pervitin through alternative ways. Such ways may include illegal activities, e.g. production or distribution of the drug, prostitution, theft, etc.: "... when you are in the street, without a job, without money, you must get it somehow, although you are not proud of yourself then." (M, 28 years).

Another source of funds may consist of social benefits. Some users use them because it is convenient for them to get some money each month without having to go to work: "It is actually favourable for me to be registered in the employment 
office; if I went to work, I would have almost the same money." (V., 30 years). But there may also be opposite cases of persons who would have the right to the benefits, but they do not make use of that source because they are discouraged by the proceedings within which they would have to go to the respective authorities in person and to speak with the clerks: "Well, employment offices and so on, there always are problems, they look at me and when I say that I need money, they are clear about that I need them for the drugs, yeah. They see a druggie in me straight away, and that's it." (D., 35 years).

Housing problems are connected with the drug abuse too. The individuals using pervitin may face situations when they search a flat for rent, but the flat owner does not provide them with the housing because of their appearance or behaviour: "We had arranged a visit to a flat that was near a squat; we dropped by to say hello to a friend and the flat owners probably saw us because they didn't open us the door and didn't answer the phone either." (T., 28 years). Sooner or later, the drug addiction may deprive the individual of housing, and therefore the individual gets to the street, to squats, to garages, etc.

If focusing on the social dimension of social exclusion, we must mention the experience of pervitin users with surrounding people. During the drug career of addicted persons, people avoid their company. "Normal people look weirdly at me." (E., 28 years). In connection with that fact, the users do not seek contacts with nonusers, and their social network consists primarily or exclusively of other drug addicted persons: "I don't have contacts with the people I met before; I meet my acquaintances who actually understand me; other people look down their nose at me." (J., 24 years). The fact that the users withdraw from contacts with persons who do not use drugs supports their alienation from the majority society.

Within the cultural dimension of social exclusion of problematic drug users, we can speak of the creation of so-called "drug (sub)culture" with own rules and with a characteristic style of life concerning the use of illegal drugs. The subculture members can be involved in achieving their common goals, like getting drugs, seeking money for their purchase or trying to keep secret against the majority society: "You are quite daily with those people, you arrange where you can get the substance, for how much many, somebody takes you there, it's quite a daily matter." (T., 31 years). Moshier et al. (2012) add hat the drug users experience excitement and efficiency resulting from the illegal activities within the subculture. But the membership in the subculture is accompanied by separation from individuals not belonging to the given subculture.

The fourth dimension of social exclusion is a symbolic dimension. Within it, the pervitin users often face stigmatization and condemnation by the majority society. Based on generally rooted stereotypes and prejudices maintained in the majority society, such individuals are displaced to the margin of the society: ,Well, it is quite simple, they look differently at you and turn against you straight away. They look at you differently, you are simply a druggie for them." (E., 28 years). Within our study, 
we describe only the subjective level of the phenomena; a comprehensive research of the given issues would be possible through a discursive analysis.

\section{Discussion}

Additionally, to the variant where drugs lead to social exclusion, Goode (2008) mentions also an opposite variant - where exclusion and the related negative feelings lead to drug abuse. But we have not encountered the latter within our research. However, with respect to the character of the study and to the sample size, we cannot generalize stating that such a situation is less frequent. Moreover, both cases may be interconnected in practice.

Interconnections occur within the individual dimensions of social exclusion. Economic impacts of exclusion are primarily manifested by unemployment, typical for drug-addicted persons. Mravčík et al. (2015) state that about 18\% of regular drug users (more frequently men) have regular employment. Therefore the drug users often make use of different alternative strategies to get subsistence. For example and typically - there is a bilateral relation between the abuse of habit-forming substances and provision of commercial sexual services. Former (abstaining) female drug users are increasingly involved in the sex business, as they hare reduced chances in the labour market because of their drug abuse past. Approximately 20$25 \%$ of female sex workers in the Czech Republic are addicted to drugs (Rozkoš bez rizika 2014). Similar strategies lead to further exclusion and stigmatization of the users, contributing to the creation of the spiral of exclusion. A consequence and cause at the same time is also the fact that socially excluded people communicate almost exclusively with others.

\section{Conclusion}

The Czech Republic has had an increasing number of people suffering from serious drug addiction problems recently. In 2014 , there were 47.700 problematic users in the total population. The most frequently used drugs include methamphetamine (pervitin) and cannabis. Although the problematic users or drug-addicted persons are aware of the prevailing positive sides of the abstinence, they keep abusing drugs. The informants are more or less aware of their very risky behaviour. At the same time, life with addiction is very attractive for them, in spite of all negative sides.

\section{Conflict of interest statement}

None. 


\section{Bibliography}

1. Buchanan J. (2005): Missing links? Problem drug use and social exclusion. The Journal of Community and Criminal Justice 2005; 51(4): 389-99. DOI: https://doi.org/10.1177/0264550504048246

2. Flick U. (2009): An Introduction to Qualitative Research. London: Sage.

3. Goode E. (2008): Drugs in American society, 7th edition. Boston: McGrawHill.

4. MacDonald R. (2006): Social exclusion, youth transitions and criminal careers: Five critical reflections on 'risk' The Australian and New Zealand. Journal of Criminology. 2006; 39(3), 371-83. DOI: https://doi.org/10.1375/acri.39.3.371

5. Moshier SJ, McHugh RK, Calkins AW, Hearon BA, Rosellini AJ, Weitzman ML, Otto MW. (2012): The role of perceived belongingness to a drug subculture among opioid-dependent patients. Psychology of Addictive Behaviors; 26(4): 812-20. DOI: https://doi.org/10.1037/a0029107

6. Mravčík V. (2015): Výroční zpráva o stavu ve věcech drog v České republice v roce 2014. Praha: Úřad vlády ČR.

7. Neale J. (2006): Social exclusion, drugs and policy. In: Hughes R, ed. Drugs, policy and politics. Maidenhead: McGraw-Hill/Open University Press.

8. Popay J, Escorel S, Hernández M, Johnston H, Mathieson J, Rispel L. (2008): Understanding and Tackling Social Exclusion. Final Report to the WHO Commission on Social Determinants of Health From the Social Exclusion Knowledge Network.

9. Rozkoš bez rizika. (2014): Analýza sociodemografických dat a rizikového chování klientek programu organizace Rozkoš bez rizika.

10. Ryczkowska A. (2009): Alkoholismus a sociální vyloučení. In: Problémy sociálního vyloučení-vybrané aspekty. [Online] [Cit. 2014-06-15 ] Dostupné z: http://www.ropsopole.pl/pobierz/projektpradziad/Problemy_wykluczenia_spole cznego-wybrane_aspekty_CZ.pdf

11. Ziyauddin KM, Kasi E. (2009): Dimensions of Social Exclusion: Ethnographic Explorations. Newcastle upon Tyne: Cambridge scholars publishing. 